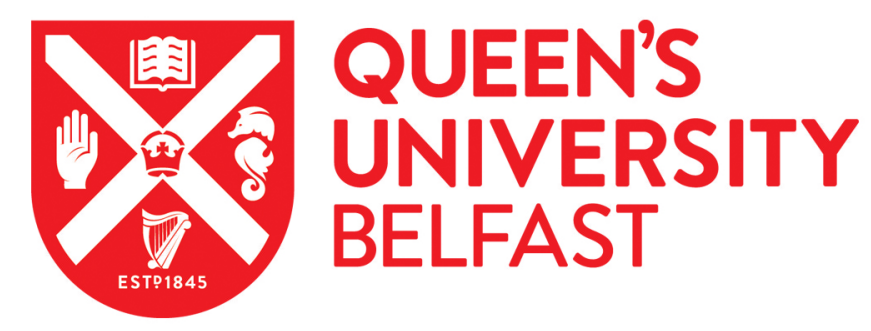

\title{
Mechanism analysis of tartrazine biosorption onto masau stones; a low cost by-product from semi-arid regions
}

\author{
Albadarin, A., Charara, M., Tarboush, B. J. A., Walker, G., Kurniawan, T. A., Ahmad, M., Naushad, M., \& \\ Mangwandi, C. (2017). Mechanism analysis of tartrazine biosorption onto masau stones; a low cost by-product \\ from semi-arid regions. Journal of Molecular Liquids, 242, 478-483. https://doi.org/10.1016/j.molliq.2017.07.045
}

Published in:

Journal of Molecular Liquids

Document Version:

Peer reviewed version

Queen's University Belfast - Research Portal:

Link to publication record in Queen's University Belfast Research Portal

\section{Publisher rights}

Copyright 2017 Elsevier.

This manuscript is distributed under a Creative Commons Attribution-NonCommercial-NoDerivs License

(https://creativecommons.org/licenses/by-nc-nd/4.0/), which permits distribution and reproduction for non-commercial purposes, provided the author and source are cited.

\section{General rights}

Copyright for the publications made accessible via the Queen's University Belfast Research Portal is retained by the author(s) and / or other copyright owners and it is a condition of accessing these publications that users recognise and abide by the legal requirements associated with these rights.

Take down policy

The Research Portal is Queen's institutional repository that provides access to Queen's research output. Every effort has been made to ensure that content in the Research Portal does not infringe any person's rights, or applicable UK laws. If you discover content in the Research Portal that you believe breaches copyright or violates any law, please contact openaccess@qub.ac.uk. 
1 Mechanism analysis of tartrazine biosorption onto masau stones; a low cost by-product

\title{
from semi-arid regions
}

\author{
Ahmad B. Albadarin ${ }^{1,2 *}$, M. Charara ${ }^{3}$, B.M. Abu Tarboush ${ }^{3}$, M.N.M Ahmad ${ }^{3}$, \\ Tonni Agustiono Kurniawan ${ }^{4}$, Mu Naushad ${ }^{5}$, G.M. Walker ${ }^{1}$ and C. Mangwandi ${ }^{2}$ \\ ${ }^{I}$ Department of Chemical and Environmental Science, Bernal Institute, University of Limerick, Limerick, Ireland. \\ ${ }^{2}$ School of Chemistry and Chemical Engineering, Queen's University Belfast, Belfast BT9 5AG, Northern Ireland \\ UK. \\ ${ }^{3}$ Faculty of Engineering and Architecture American University of Beirut, Beirut, Lebanon. \\ ${ }^{4}$ College of Ecology and Environment, Xiamen University, Xiamen 361102 Fujian Province, PR China. \\ ${ }^{5}$ Department of Chemistry, College of Science, King Saud University, Riyadh-11451, Saudi Arabia.
}

\section{Abstract}

The removal of tartrazine from aqueous solutions using masau stone (MS) as a novel low-cost biosorbent was investigated. The impact of several influential parameters such as; initial $\mathrm{pH}$, contact time, initial concentration and temperature on the biosorption process of tartrazine was studied and optimized. The mechanisms of tartrazine removal by the MS biosorbent and their kinetics and isotherm studies are also presented. It was observed that the efficiency of the removal of tartrazine depends on the $\mathrm{pH}$ of the solution and the maximum efficiency (approx. $87 \%$ at $C_{\mathrm{o}}=100$ ) was found at $\mathrm{pH} 2$. Kinetic studies were well suited and found to be in good agreement with the pseudo-second order model. The biosorption equilibrium data was adequately described by the Langmuir isotherm model at $20^{\circ} \mathrm{C}$ and $30{ }^{\circ} \mathrm{C}$. High temperatures seem to promote multilayer biosorption as the tartrazine experimental data best fits both Freundlich and Redlich-Peterson isotherms $\left(R^{2}=0.996\right.$ for both). The maximum biosorption capacities of tartrazine were between; $0.096 \mathrm{mmol} / \mathrm{g}(51.3 \mathrm{mg} / \mathrm{g})$ at $20{ }^{\circ} \mathrm{C}$ and $0.126 \mathrm{mmol} / \mathrm{g}$ $(65.1 \mathrm{mg} / \mathrm{g})$ at $60{ }^{\circ} \mathrm{C}$. The thermodynamic parameters obtained indicated a positive and low value of $\Delta \mathrm{H}^{\circ}$, suggesting an endothermic and physical nature process with biosorption mechanisms related to $\mathrm{H}$-bonds, van der Waals and electrostatic interactions. The results clearly indicated that masau stone would be a suitable biosorbent for the anionic dye, tartrazine, from contaminated wastewater under specific conditions.

Keywords: Azo Dye; Tartrazine; Masau Biomass; By-Products; Biosorption; Wastewater treatment.

\footnotetext{
*Correspondence author: Email: Ahmad.B.Albadarin@ul.ie
} 


\section{Introduction}

The discharge of effluents that contain synthetic dyes is a major concern to the environment and aquatic life due to the hazards associated with toxicity and the large quantity of dye-loaded wastewater released [1-3]. For instance, the textile industry alone manufactures an extraordinary 60 billion kgs of fabric per annum, using up to $9 \times 10^{12}$ gallons of water. About $10-25 \%$ of textile dyes could not be recovered during the dyeing process, and $2-20 \%$ is discharged as aqueous effluents into different environmental components with an estimated 800,000 tons of synthetic dyes produced each year and $\sim 50 \%$ of these classified as azo dyes [4-6]. Many of these synthetic dyes and their breakdown products released are carcinogenic or mutagenic to life forms, primarily due to carcinogens such as naphthalene, benzidine, and other aromatic compounds [4]. Also, most of these dyes have a recalcitrant and inhibitory nature because of their large size and complex molecular structures and are thus considered non-oxidizable by conventional physical and biological treatments. For these reasons, a large number of recent studies have been focused on the elimination and treatment of dye-bearing effluents. Various methods such as coagulation/flocculation, adsorption/biosorption, ionexchange and chemical precipitation have been employed for the treatment of dye-polluted water [7-11]. A biosorption-based treatment process provides a number of advantages when compared to the conventional technologies utilized, especially when using cheap and readily available biosorbents. These biosorbents can be produced using inexpensive growth media or obtained as a by-product from industry. Biosorption has many beneficial features including; the selective removal of ions/molecules over a broad range of temperatures and $\mathrm{pH}$ values, a negligible amount of chemical/biological sludge, its fast kinetics of adsorption and desorption (possibility of biosorbent regeneration) and low capital and operation cost [1, 8, 12-15]. Recently, the search for low-cost materials which are able to remove unwanted pollutants from contaminated water has intensified [16]. Materials locally available in large quantities such as 

no processing. Their use as an adsorbent for water purification would not only add to their economic value, but also help industries reduce the cost of waste disposal and provide a potential alternative to activated carbon [17]. Thus, in this study, masau stone by-products have been used for the biosorption of an ionic dye from aqueous solutions. The masau (Ziziphus mauritiana) tree typically grows in arid and semi-arid regions around the world. Its fruit is one of the most commonly utilized wild fruits in Zimbabwe. Extracts from the fruits, roots, leaves, seeds, and bark of the masau tree are utilized as traditional medicines to treat the effects of skin diseases, inflammatory conditions, insomnia and fever. For these reasons, the masau tree plays an important role in the integrated economy of arid regions [18]. To date, there are no systematic studies of the use of masau fruits and shells in the removal of pollutants, despite the large quantities of waste product generated as a result of processing the fruit. Tartrazine (TZ) is a major contaminant in the environment. Tartrazine, a coal tar derivative, is a very popular azo dye extensively used in food-stuffs, medicines, cosmetics and textile manufacturing [19]. Due to the hydrophilic nature of tartrazine, its presence can be noticed as a yellow menace in effluents. Contact with the dye results in many kinds of health issues including: skin eczema, hypersensitivity, allergies, asthma, mutagenic and carcinogenic effects and immunosuppressive effects [5]. The studies dealing with the removal of tartrazine (TZ) using raw biosorbents such as masau stone (MS) are rare and therefore, tartrazine was selected as a model dye. The key aims of the current investigation are to (i) examine the effect of influential factors including solution $\mathrm{pH}$, initial dye concentration and contact time on the biosorption process, and (ii) determine the mechanism of TZ biosorption onto MS and the type of TZ-MS interactions occurring by applying a range of equilibrium and kinetic models and analytical techniques to the biosorption experimental data. 


\section{Materials and methods}

\subsection{Masau stone biosorbent}

Masau stone (MS) biomass, was collected and mechanically crushed. After which, the biosorbent was repeatedly washed with boiled water and finally with distilled water, and dried at $110{ }^{\circ} \mathrm{C}$ for $24 \mathrm{hrs}$. After sieving, approx. $70 \%$ of MS particles had a mean diameter in the range of $350-500 \mu \mathrm{m}$. This particle size was therefore used for the biosorption experiments. The specific surface area of masau stone was measured by the $\mathrm{N}_{2}$-BET method as $27.66 \mathrm{~m}^{2} / \mathrm{g}$.

\subsection{Methods}

Tartrazine $(534.3 \mathrm{~g} / \mathrm{mol})$ was purchased from Sigma Aldrich, UK. All chemicals were of analytical grade and used without further purification. Hydrochloric acid $(\mathrm{HCl})$ and sodium hydroxide $(\mathrm{NaOH})$ were used for the $\mathrm{pH}$ adjustment. Synthetic tartrazine stock solution was prepared with distilled water (resistivity $18.24 \Omega \mathrm{cm}$ ). Batch biosorption studies were performed in a series of $50 \mathrm{~cm}^{3}$ glass jars on a mechanical shaker. For each experimental point, $25 \mathrm{~cm}^{3}$ of a stock solution was first added into the glass jar and then the masau stone biosorbent was added and maintained under shaking in a regulated speed shaker $(100 \mathrm{rpm}$, biomass dosage $4.0 \mathrm{~g} / \mathrm{dm}^{3}$ and $20^{\circ} \mathrm{C}$ for $\left.96 \mathrm{hrs}\right)$. After the biosorption, the samples were filtered and analysed for tartrazine concentration. The biosorption process was studied as a function of $\mathrm{pH}(2-11)$ with $C_{\mathrm{o}}$ of $0.187 \mathrm{mM}$ and biomass dosage $4.0 \mathrm{~g} / \mathrm{dm}^{3}$, initial tartrazine concentration (0.057$0.861 \mathrm{mM}$ ) and contact time. After reaching equilibrium, the concentration of tartrazine in the aqueous solution was analysed by UV analysis, performed on a UV-Visible spectrophotometer (Perkin Elmer LAMBDA 25, UK) at a maximum wavelength $\lambda_{\max }=426 \mathrm{~nm}$.

Tartrazine (TZ) uptake, $q(\mathrm{mmol} / \mathrm{g})$, and percentage of removal (\%) were calculated according to Eq. (1) and (2), respectively:

107

$$
q=\left[\frac{C_{o}-C_{e}}{M}\right] \times V
$$


108 The removal efficiency $(\%)=\left[1-\frac{C_{e}}{C_{o}}\right] \times 100 \%$

109 where $C_{\mathrm{o}}$ and $C_{\mathrm{e}}$ are the initial and equilibrium concentrations of tartrazine (TZ) in $\mathrm{mM}, M$ is

110 the amount of dry biomass in grams and $V$ is the volume of the tartrazine (TZ) solution in $\mathrm{dm}^{3}$.

\section{$111 \quad 3 . \quad$ Results and discussion}

\section{$112 \quad 3.1 . p H$ experiment}

113 The $\mathrm{pH}$ of the solution has a critical role when it comes to controlling the dissociation of

114 different functional groups on the biosorbent active sites, as well as its surface charge, and the 115 extent of ionization of the adsorbate in the solution [20]. The effect of initial solution $\mathrm{pH}$ on

116 the removal of tartrazine was carried out in the range of $2-11$ as illustrated in Figure 1.

117 Biosorption of $\mathrm{TZ}$ by masau stone biomass was particularly dependent on the $\mathrm{pH}$ of the dye

118 solution. At a pH value of around 2, the masau stone (MS) surface is more positively charged

119 through increased functional groups protonation, than at higher $\mathrm{pH}$ values. The removal

120 efficiency decreased from $87 \%$ to $15 \%$ when the solution $\mathrm{pH}$ was increased from 2.18 to 11.0 ,

121 following typical anionic adsorption/biosorption behaviour. The mechanisms of the

122 biosorption process of TZ onto MS were mainly due to the electrostatic attractions of the

123 tartrazine molecules with protonated functional groups such as hydroxyl, carbonyl and amine

124 groups of the masau stone at $\mathrm{pH}<\mathrm{pHpzc}$. Conversely, at higher $\mathrm{pH}$, the number of protonated

125 functional groups decreases and more $\mathrm{OH}^{-}$ions compete with anionic dye ions for the

126 biosorption sites. At alkaline $\mathrm{pH}$, the covalent coordination bonds between sodium ions and

127 the surface functional group of masau stone, such as carboxylic and sulfonic acid are very weak

128 in basic condition. As a result, the number of protonated functional groups decreases and more

$129 \mathrm{OH}^{-}$ions compete with the anionic ions of the adsorbate for the sorption sites, leading to a

130 lower removal of tartrazine by the adsorbent. Similar trends were reported for the removal of 131 tartrazine using hen feathers [19], activated carbon biosorbents of Lantana camara [21] and 
132 Spirulina platensis [22]. Therefore, $\mathrm{pH} 2$ was used for subsequent runs of the biosorption experiments.

\subsection{Biosorption kinetics}

135 The biosorption kinetics are used for the determination of the rate controlling mechanism of

136 biosorption processes such as; biosorption on surface and chemical reaction or diffusion

137 mechanisms. The pseudo-first order kinetic model assumes that the rate of change in the solute concentration over time is logarithmic proportional to changes in the saturation concentration and the amount of absorbent over time [23,24]. The pseudo-first order model equation is given as follows [25]:

$$
q_{t}=q_{e}\left(1-e^{-k_{1} t}\right)
$$

142 The pseudo-second order equation is given as [26]:

$$
q_{t}=\frac{k_{2} q_{e}^{2}}{\left(1+k_{2} q_{e} t\right)} t
$$

144 where $k_{1}$ is the pseudo-first order kinetic constant $(1 / \mathrm{min})$ and $k_{2}$ is the constant of the pseudosecond order kinetics $(\mathrm{g}(\mathrm{mmol} / \mathrm{min}))$.

146 The results of the kinetic biosorption studies are shown in Figure 2. The parameters of the

147 kinetics equations are given in Table 1 . The most accurate model was considered based on the

148 determination coefficient $\left(R^{2}\right)$. It can be observed that the kinetics of TZ removal by masau

149 stone followed the pseudo-second order model for the seven $\mathrm{TZ}$ initial concentrations 150 employed in the present study. These results suggested that the pseudo-second order

151 biosorption mechanisms are predominant. Furthermore, the nonlinear relationship between the

152 initial dye concentration and the rate constant indicates that mechanisms such as; ion exchange,

153 chelation and physical adsorption may be involved in the biosorption process. 
It is very important to realise that adsorption/biosorption mechanisms (chemical bonding or chemisorptions) cannot simply be determined based on carrying out kinetic experiments or by

fitting kinetic models. In this case, analytical methods and/or adsorptive thermodynamic data

(i.e., changes in enthalpy and entropy) and activation energies, are essential to confirm that the removal process is either physical or chemical.

The intra-particle diffusion model was used to investigate the mechanism involved in the biosorption process. Assuming that the rate is controlled by pore and intra-particle diffusion,

161 the amount biosorbed $\left(q_{\mathrm{t}}\right)$ is proportional to the square root of time $\left(t^{0.5}\right)$ in a non-flow-agitated system, according to the relationship given by Weber and Morris [27]:

$$
q_{t}=k_{i d} \times t^{0.5}+C_{i d}
$$

$163 k_{\text {id }}\left(\mathrm{mg} / \mathrm{g} \cdot \mathrm{min}^{0.5}\right)$ is the intra-particle diffusion rate constant and $C_{\text {id }}$ is proportional to the 164 boundary layer thickness.

165 The intra-particle diffusion model [28] was plotted in order to verify the influence of mass

166 transfer resistance on the binding of $\mathrm{TZ}$ to the masau stone (Table 2 and Figure 3 ). Thus, the

167 intra-particle diffusion constant, $k_{\text {id }}\left(\mathrm{mg} / \mathrm{g} \cdot \mathrm{min}^{0.5}\right)$, can be obtained from the slope of the plot of $168 q_{t}$ (uptake at any time, $\mathrm{mg} / \mathrm{g}$ ) versus the square root of time. If this plot passes through the 169 origin, then intra-particle diffusion is the rate controlling step. Figure 3 shows the plots of $q_{\mathrm{t}}$ 170 versus $t^{0.5}$, with multi-linearity though, none of the plots passed through the origin $\left(C_{\mathrm{id}} \neq 0\right)$,

171 which implies that the process involves more than one kinetic stage (or sorption rate); external

172 surface biosorption or the instantaneous biosorption stage is not the main rate controlling step $173[28,29]$. It can be seen from Table 2 that the values of $k_{\text {id }}$ increase with the increase of initial 174 dye concentration. This is due to the effect of potential force as a result of the gradual change 175 in concentration. 
177 Since the equilibrium isotherm is of vital importance to the adsorption system for the removal

178 of dye from an aqueous solution, it is essential to establish the most suitable correlation for the 179 equilibrium curves [20, 30]. In this study, three of the most commonly used models: Langmuir 180 [31], Freundlich [32] and Redlich-Peterson [33], were employed to describe the equilibrium 181 isotherm of the dye removal experiment. Linear forms of isotherm models are unable to provide 182 a fundamental understanding of the ion adsorption systems, resulting in improper conclusions. Therefore, non-linear regression in SigmaPlot11 was used to fit the isotherm models to the experimental data at different solution temperatures and the summary of the fits is presented in Table 3 and Figure 4. There was an initial increase in the amount of biosorbed dye per unit mass of MS, but that amount later started following a plateau evolution at higher solution concentrations. At $20{ }^{\circ} \mathrm{C}$, the $q_{\max }$ value was measured as $0.096 \mathrm{mmol} / \mathrm{g}$; this is equivalent to approx. $51.3 \mathrm{mg} / \mathrm{g}$. Also, it is found that the tartrazine experimental data best fits both Langmuir and Redlich-Peterson isotherms $\left(R^{2}=0.986\right.$ and 0.985 , respectively) with the

190 Redlich-Peterson constant value, $\beta$, close to unity (0.835). This specifies a homogeneous surface binding and that the Redlich-Peterson isotherm is approaching the Langmuir form and not the Freundlich isotherm [34]. It is also shown in Table 3 that, at $20^{\circ} \mathrm{C}$, the magnitude of the Langmuir constant $b$ was $6.460 \mathrm{dm}^{3} / \mathrm{mmol}$. The maximum biosorption capacity $20{ }^{\circ} \mathrm{C}$ was

194 found to be $0.096 \mathrm{mmol} / \mathrm{g}$. The $1 / n$ value shown in Table 3 for the Freundlich model indicates 195 that the strength of the biosorption process is related to the distribution of energy sites. In real 196 life, wastewater from different industries is discharged at a wide range of temperatures based 197 on the process that generates the effluents. Accordingly, studying the effect of temperature on 198 dye adsorption is very crucial. The effect of temperature increase on the biosorption isotherm equilibrium is presented in Table 3 . Increasing the temperature from 20 to $60{ }^{\circ} \mathrm{C}$ increased the

200 values of the Langmuir constants, $b$ and $q_{\max }$, and $K_{F}$ with a more pronounced increase in the 
201 value of $b$. This reflects the endothermic nature of the biosorption of TZ molecules on the

202 surface of the MS. This increase in biosorption capacity at high temperature might be due to more available sites for biosorption and strong interaction forces between the TZ dyes molecules and the MS surface. On the other hand, a slight decrease in the values of $1 / n$ and the Redlich-Peterson constant value, $\beta$, are found as a result of increasing the temperature. High temperatures seem to promote multilayer biosorption as the tartrazine experimental data best

207 fits both Freundlich and Redlich-Peterson isotherms $\left(R^{2}=0.996\right.$ for both $)$. A brief comparison of the $q_{\text {max }}$ values obtained in this study to other materials is presented in Table $4[19,22,35-$ 37]. The biosorption capacity of $\mathrm{TZ}$ onto masau stone is average among the materials listed.

210 However, the use of the masau biosorbent for anionic dye removal is very promising since it is 211 cheap and readily available in many countries.

\subsection{Thermodynamic parameters}

213 In order to better understand the nature and mechanism of the TZ dyes biosorption onto the

214 MS surface, biosorption data at different temperatures, were used to calculate thermodynamic 215 parameters such as change in enthalpy $\left(\Delta \mathrm{H}^{\circ}\right)$, change in free Gibbs energy $\left(\Delta \mathrm{G}^{\circ}\right)$ and change 216 in entropy $\left(\Delta \mathrm{S}^{\circ}\right)$ Eqs. (6) to (8):

$217 \Delta G^{o}=-R T \ln 55.5 \times b \times 1000$

$218 \Delta G^{o}=\Delta H^{o}-T \Delta S^{o}$

$\ln 55.5 \times b \times 1000=\frac{\Delta S^{o}}{R}-\frac{\Delta H^{o}}{R} \frac{1}{T}$

where $R$ is the universal gas constant $(8.314 \mathrm{~J} / \mathrm{mol} \mathrm{K})$. The term $55.55\left(\mathrm{~mol} / \mathrm{dm}^{3}\right) \times b$

$221\left(\mathrm{dm}^{3} / \mathrm{mmol}\right) \times 1000$ is dimensionless.

222 The above equation was used to find the slope and intercept which represent the values of $223\left(\Delta \mathrm{H}^{\circ}\right)$ and $\left(\Delta \mathrm{S}^{\circ}\right)$ respectively. Estimated thermodynamic parameters, change in enthalpy $224\left(\Delta \mathrm{H}^{\circ}\right)$, change in free Gibbs energy $\left(\Delta \mathrm{G}^{\circ}\right)$ and change in entropy $\left(\Delta \mathrm{S}^{\circ}\right)$ are presented in Table 
226 values of $\Delta \mathrm{G}^{\circ}$ and positive values of $\Delta \mathrm{S}^{\circ}$ and $\Delta \mathrm{H}^{\circ}$ indicate that the biosorption process is

227 spontaneous. Moreover, the increase in temperature reduced the values of $\Delta \mathrm{G}^{\circ}$ which

228 emphasize the spontaneity of the biosorption process at a high temperature. Upon increasing

229 the temperature, the absolute values of $\Delta \mathrm{G}^{\circ}$ increased, indicating that the biosorption also

230 increased. This finding agrees with the reported values of biosorption capacity at different

231 temperatures in Table 3. Additionally, it can be observed that the energies involved in the

232 process $(\approx 13 \mathrm{~kJ} / \mathrm{mol})$ are within the range of the intermolecular interactions characteristic

233 binding energy of physical bonding: hydrogen bonds $(4-13 \mathrm{~kJ} / \mathrm{mol})$ and electrostatic attractions

$234(6-80 \mathrm{~kJ} / \mathrm{mol})$.

235

\subsection{FTIR and SEM analysis}

236

The occurrence of moderately negatively charged groups in the tartrazine structure, such as

$\mathrm{COOH}, \mathrm{SO}_{3}$, and $\mathrm{OH}$ allows the formation of columbic forces, hydrogen bonds, covalent bonds or weak van der Waals forces [38]. The FTIR, Figure 5, shows a number of absorption peaks suggesting complex properties of biosorption capabilities of masau. The dominant peak at $35001 / \mathrm{cm}$ is attributed to both surface hydroxyl $(\mathrm{OH})$ stretching of carboxylic groups and also stretching of amide groups (-NH) [39]. These groups are significantly involved in the hydrogen bonds. The peak at $29501 / \mathrm{cm}$ is attributed to the alkyl group $(\mathrm{C}-\mathrm{H})$ while the peak at 1750 $1 / \mathrm{cm}$ is attributed to the carbonyl group $(\mathrm{C}=\mathrm{O})$. A slight shift in the peaks within the alkyl group from 1743 to $\sim 17411 / \mathrm{cm}$ is attributed to biosorption of dye molecules. On the fresh masau stone, the $\mathrm{N}-\mathrm{C}=\mathrm{O}$ stretch peak occurs at $16501 / \mathrm{cm}$, and is absent after biosorption, suggesting that the amide group might have been involved in the biosorption. The absorption at $8701 / \mathrm{cm}$ may be related to the $\mathrm{C}-\mathrm{H}$ rocking vibrations of cellulose. A new peak appears at $16351 / \mathrm{cm}$ after biosorption. The peaks in the range of 950-1200 1/cm may represent the $\mathrm{C}-\mathrm{O}$ stretching group. The spectra also show that some peaks in the range 455 to $5551 / \mathrm{cm}$ that were present in the masau prior to biosorption were not present after biosorption. Consequently, 
the FTIR shows the availability of these different function groups that will contribute to the biosorption of TZ. The FTIR also suggests that all the intensities of the peaks are reduced due to the biosorption of $\mathrm{TZ}$ on the surface and inside the pores of the biosorbent. The mechanisms of TZ biosorption may be due to the positive charge of the dye and the hydrophobic character of the $\mathrm{TZ}$ molecules. Thus, the mechanisms of $\mathrm{TZ}$ biosorption are due to the electrostatic attraction between the functional groups and TZ. The SEM of both fresh and TZ loaded masau are shown in Figure 6. There is evidence to suggest that the surface has been changed due to the biosorption of TZ. It is also shown that the biosorbed TZ tends to make the MS morphology structures less defined.

\section{Conclusion}

261 In this investigation, detailed results were presented for biosorption of tartrazine (TZ) from aqueous solutions using masau stone (MS). The results showed that the removal of TZ onto MS fluctuates very little in the $\mathrm{pH}$ range of 4-12 but decreases with $\mathrm{pH}$ value as $\mathrm{pH}$ exceeds 2. The Langmuir isotherm model was found to fit well to the experimental data as compared to other applied isotherm models. The maximum biosorption capacity of TZ biosorbed was 0.126 $\mathrm{mmol} / \mathrm{g}$ at $60^{\circ} \mathrm{C}$. The kinetic study showed that the pseudo-second order model is suitable for describing the experimental data and that the external surface biosorption stage is not the main rate controlling step and film diffusion might be implicated in the sorption process.

\section{References}

[1] A.B. Albadarin, J. Mo, Y. Glocheux, S. Allen, G. Walker, C. Mangwandi, Preliminary investigation of mixed adsorbents for the removal of copper and methylene blue from aqueous solutions, Chemical Engineering Journal, 255 (2014) 525-534.

[2] B. Heibati, S. Rodriguez-Couto, N.G. Turan, O. Ozgonenel, A.B. Albadarin, M. Asif, I. Tyagi, S. Agarwal, V.K. Gupta, Removal of noxious dye-Acid Orange 7 from aqueous solution using natural pumice and Fe-coated pumice stone, Journal of Industrial and Engineering Chemistry, 31 (2015) 124-131.

[3] A.A. Alqadami, M. Naushad, M.A. Abdalla, M.R. Khan, Z.A. Alothman, Adsorptive Removal of Toxic Dye Using Fe3O4-TSC Nanocomposite: Equilibrium, Kinetic, and Thermodynamic Studies, Journal of Chemical \& Engineering Data, 61 (2016) 3806-3813.

[4] Zaharia Carmen, S. Daniela, Textile organic dyes - characteristics, polluting effects and separation/elimination procedures from industrial effluents - a critical overview, www.intechopen.com, 3 (2012) 55-86.

[5] S. Banerjee, M.C. Chattopadhyaya, Adsorption characteristics for the removal of a toxic dye, tartrazine from aqueous solutions by a low cost agricultural by-product, Arabian Journal of Chemistry, 10 (2017) 16291638.

[6] P. Geetha, M.S. Latha, M. Koshy, Biosorption of malachite green dye from aqueous solution by calcium alginate nanoparticles: Equilibrium study, Journal of Molecular Liquids, 212 (2015) 723-730. 

hydrogels for the effective adsorption of cationic dyes, Journal of Industrial and Engineering Chemistry, 22 (2015) 171-178.

[8] A.B. Albadarin, C. Mangwandi, Mechanisms of Alizarin Red S and Methylene blue biosorption onto olive stone by-product: Isotherm study in single and binary systems, Journal of Environmental Management, 164 (2015) 86-93.

[9] K.L. Yeap, T.T. Teng, B.T. Poh, N. Morad, K.E. Lee, Preparation and characterization of coagulation/flocculation behavior of a novel inorganic-organic hybrid polymer for reactive and disperse dyes removal, Chemical Engineering Journal, 243 (2014) 305-314.

[10] B. Makhoukhi, M.A. Didi, H. Moulessehoul, A. Azzouz, D. Villemin, Diphosphonium ion-exchanged montmorillonite for Telon dye removal from aqueous media, Applied Clay Science, 50 (2010) 354-361.

[11] I. Anastopoulos, G.Z. Kyzas, Progress in batch biosorption of heavy metals onto algae, Journal of Molecular Liquids, 209 (2015) 77-86.

[12] A.B. Albadarin, A.a.H. Al-Muhtaseb, N.A. Al-laqtah, G.M. Walker, S.J. Allen, M.N.M. Ahmad, Biosorption of toxic chromium from aqueous phase by lignin: mechanism, effect of other metal ions and salts, Chemical Engineering Journal, 169 (2011) 20-30.

[13] A.B. Albadarin, Y. Glocheux, M.N.M. Ahmad, G.M. Walker, C. Mangwandi, Novel comparison of kinetic models for the adsorption-coupled reduction of $\mathrm{Cr}(\mathrm{VI})$ using untreated date pit biomaterial, Ecological Engineering, 70 (2014) 200-205.

[14] A.B. Albadarin, C. Mangwandi, G.M. Walker, S.J. Allen, M.N.M. Ahmad, M. Khraisheh, Influence of solution chemistry on $\mathrm{Cr}(\mathrm{VI})$ reduction and complexation onto date-pits/tea-waste biomaterials, Journal of Environmental Management, 114 (2013) 190-201.

[15] A.B. Albadarin, C. Mangwandi, G.M. Walker, S.J. Allen, M.N. Ahmad, Biosorption characteristics of sawdust for the removal of Cd(II) Ions: Mechanism and thermodynamic studies, Chemical Engineering Transactions, 24 (2011) 1297-1302.

[16] T.A. Kurniawan, G.Y.S. Chan, W.-h. Lo, S. Babel, Comparisons of low-cost adsorbents for treating wastewaters laden with heavy metals, Science of The Total Environment, 366 (2006) 409-426.

[17] S. Babel, T.A. Kurniawan, Cr(VI) removal from synthetic wastewater using coconut shell charcoal and commercial activated carbon modified with oxidizing agents and/or chitosan, Chemosphere, 54 (2004) 951967.

[18] J.F. Morton, Fruits of warm climates, Indian jujube. in J. F. Morton, (ed.), Florida: Miami (1987) 272275.

[19] A. Mittal, L. Kurup, J. Mittal, Freundlich and Langmuir adsorption isotherms and kinetics for the removal of Tartrazine from aqueous solutions using hen feathers, Journal of hazardous materials, 146 (2007) 243-248.

[20] B. Heibati, M. Ghoochani, A.B. Albadarin, A. Mesdaghinia, A.S.H. Makhlouf, M. Asif, A. Maity, I. Tyagi, S. Agarwal, V.K. Gupta, Removal of linear alkyl benzene sulfonate from aqueous solutions by functionalized multi-walled carbon nanotubes, Journal of Molecular Liquids, 213 (2016) 339-344.

[21] R.K. Gautam, P.K. Gautam, S. Banerjee, V. Rawat, S. Soni, S.K. Sharma, M.C. Chattopadhyaya, Removal of tartrazine by activated carbon biosorbents of Lantana camara: Kinetics, equilibrium modeling and spectroscopic analysis, Journal of Environmental Chemical Engineering, 3 (2015) 79-88.

[22] G.L. Dotto, M.L.G. Vieira, V.M. Esquerdo, L.A.A. Pinto, Equilibrium and thermodynamics of azo dyes biosorption onto Spirulina platensis, Brazilian Journal of Chemical Engineering, 30 (2013) 13-21.

[23] M. Kitis, E. Karakaya, N.O. Yigit, G. Civelekoglu, A. Akcil, Heterogeneous catalytic degradation of cyanide using copper-impregnated pumice and hydrogen peroxide, Water Research, 39 (2005) 1652-1662.

[24] A.B. Albadarin, M.N. Collins, M. Naushad, S. Shirazian, G. Walker, C. Mangwandi, Activated ligninchitosan extruded blends for efficient adsorption of methylene blue, Chemical Engineering Journal, 307 (2017) 264-272.

[25] S. Lagergren, About the theory of so-called adsorption of soluble substances, Kungliga Svenska Vetenskapsakademiens Handlingar 24 (1898) 1-39.

[26] Y.-S. Ho, G. McKay, Pseudo-second order model for sorption processes, Process biochemistry, 34 (1999) 451-465.

[27] W. Weber, J. Morris, Proceeding of the International Conference on Water Pollution Symposium, Pergamon Press, Oxford, 2 (1962) 235-266.

[28] S. Allen, G. McKay, K. Khader, Intraparticle diffusion of a basic dye during adsorption onto sphagnum peat, Environmental pollution, 56 (1989) 39-50. 
[29] C. Mangwandi, A.B. Albadarin, Y. Glocheux, G.M. Walker, Removal of ortho-phosphate from aqueous solution by adsorption onto dolomite, Journal of Environmental Chemical Engineering, 2 (2014) 1123-1130. [30] N.S. Maurya, A.K. Mittal, P. Cornel, E. Rother, Biosorption of dyes using dead macro fungi: effect of dye structure, ionic strength and $\mathrm{pH}$, Bioresource technology, 97 (2006) 512-521.

[31] I. Langmuir, The adsorption of gases on plane surfaces of glass, mica and platinum, Journal of the American Society, 40 (1918) 1361-1403. [32] H.M.F. Freundlich, Over the adsorption in solution, The Journal of Physical Chemistry 57 (1906) 385471. $1024-1024$.

[34] A.B. Albadarin, Z. Yang, C. Mangwandi, Y. Glocheux, G. Walker, M.N.M. Ahmad, Experimental design and batch experiments for optimization of $\mathrm{Cr}(\mathrm{VI})$ removal from aqueous solutions by hydrous cerium oxide nanoparticles, Chemical Engineering Research and Design, 92 (2014) 1354-1362.

[35] A. Mittal, J. Mittal, L. Kurup, Adsorption isotherms, kinetics and column operations for the removal of hazardous dye, Tartrazine from aqueous solutions using waste materials - bottom ash and de-oiled soya, as adsorbents, Journal of hazardous materials, 136 (2006) 567-578.

[36] L. Monser, N. Adhoum, Tartrazine modified activated carbon for the removal of $\mathrm{Pb}$ (II), $\mathrm{Cd}$ (II) and $\mathrm{Cr}$ (III), Journal of hazardous materials, 161 (2009) 263-269.

[37] W.S.W. Ngah, N.F.M. Ariff, M.A.K.M. Hanafiah, Preparation, characterization, and environmental application of crosslinked chitosan-coated bentonite for tartrazine adsorption from aqueous solutions, Water, Air, and Soil Pollution, 206 (2010) 225-236. [38] M.A. Habila, Z.A. Alothman, R. Ali, A.A. Ghafar, M.S.E.-D. Hassouna, Removal of Tartrazine Dye onto Mixed-Waste Activated Carbon: Kinetic and Thermodynamic Studies, CLEAN - Soil, Air, Water, 42 (2014) 1824-1831. 


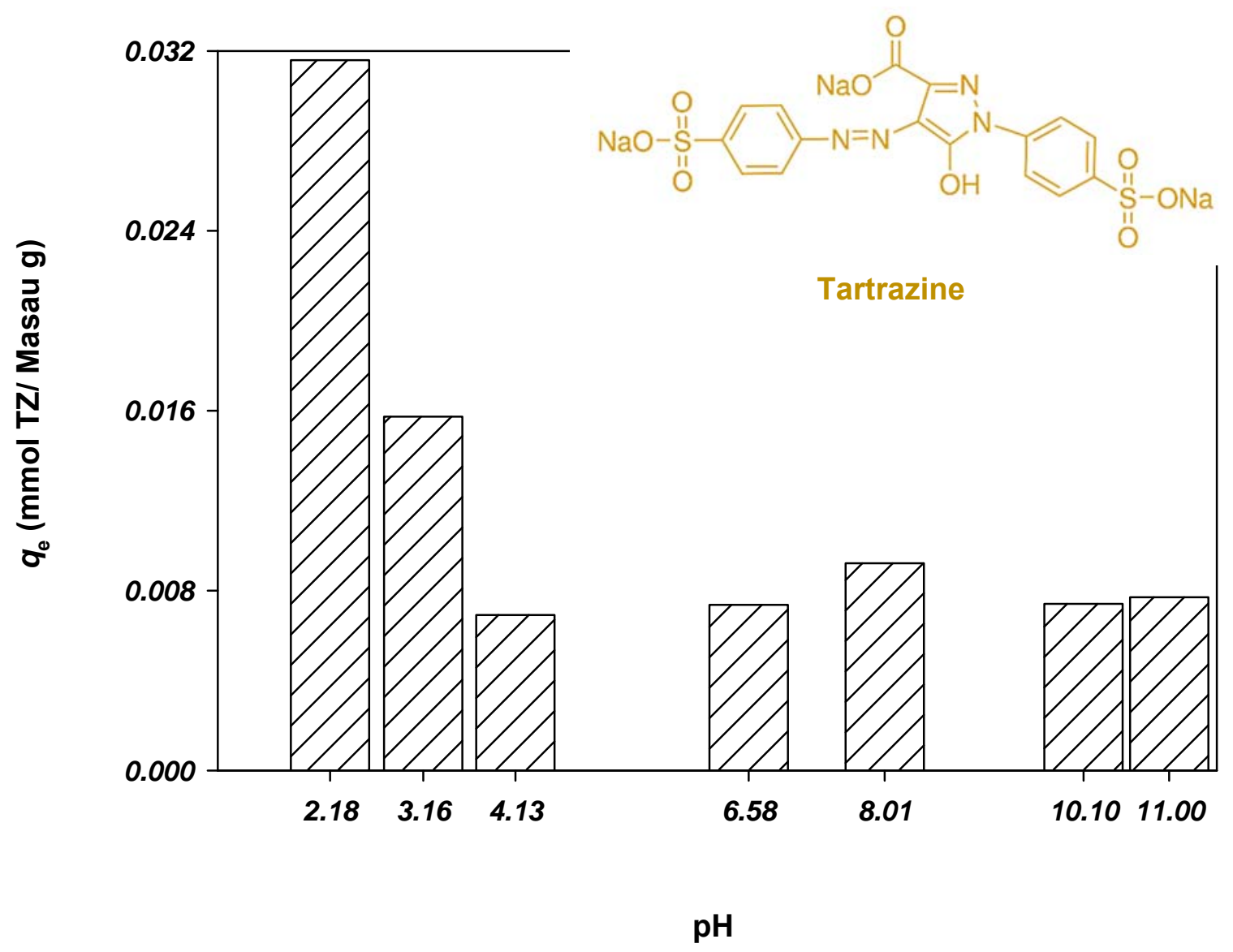

382 Figure 1: Effect of solution $\mathrm{pH}$ on the biosorption of tartrazine (TZ) onto masau stone (MS). 

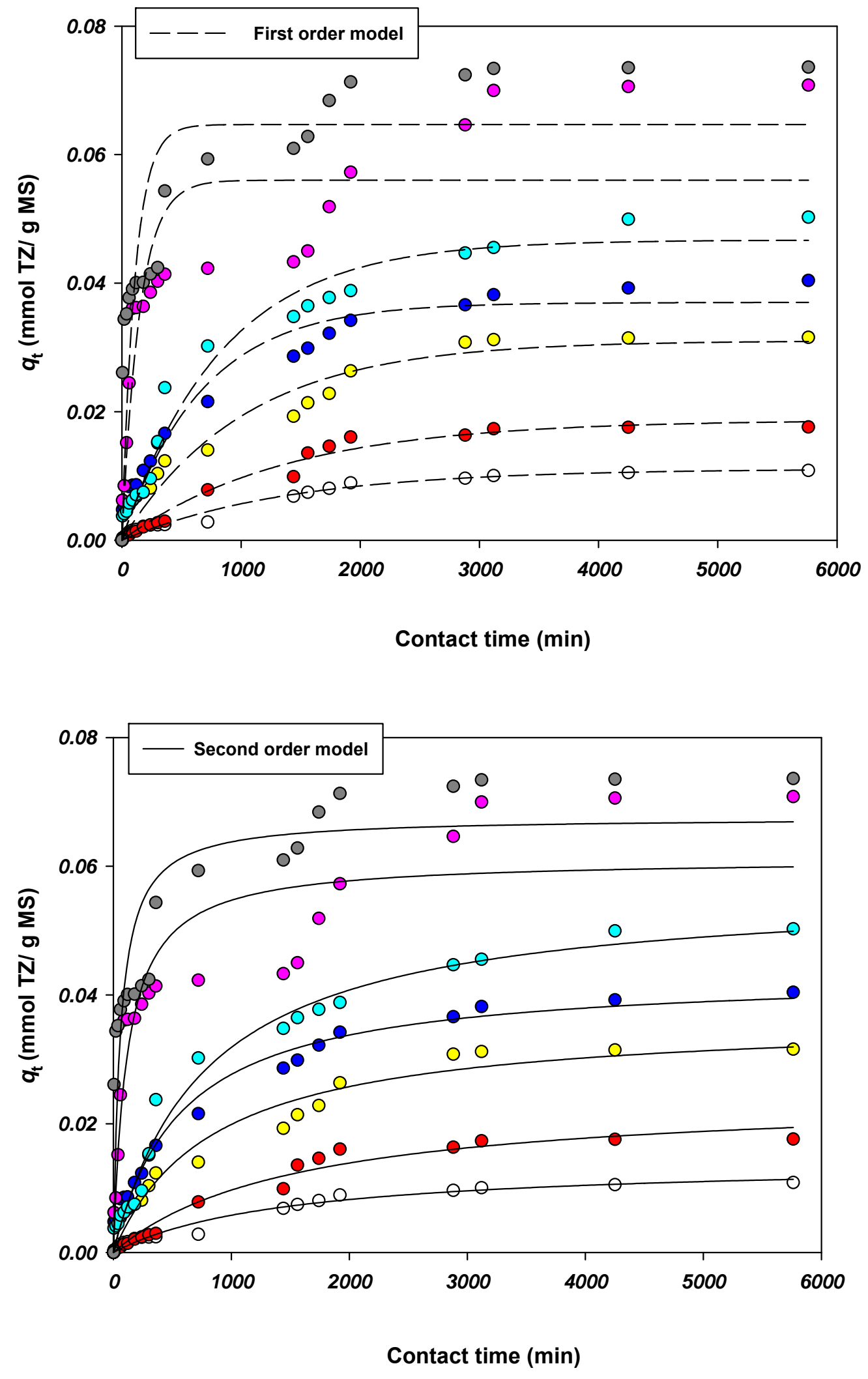

385 
386 Figure 2: Biosorption kinetics of TZ removal onto MS at different concentrations (Increasing $387 C_{\mathrm{o}}: 0.057,0.102,0.189,0.313,0.381,0.600$ and $\left.0.861 \mathrm{mM}\right)$ and fitting of pseudo first and 388 second order kinetics models.

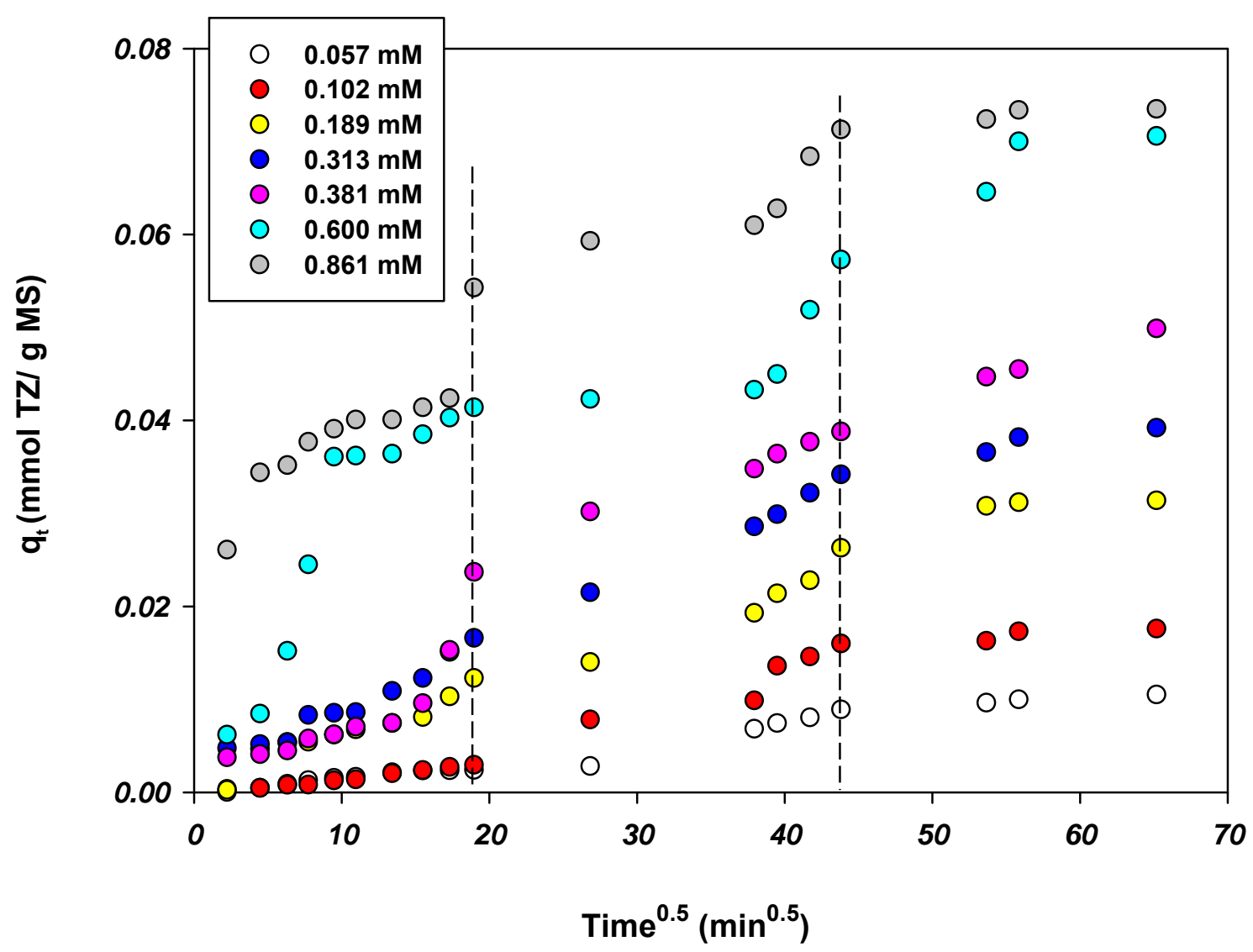

389

390 Figure 3: Intra-particle diffusion for TZ biosorption by MS.

391

392

393

394 


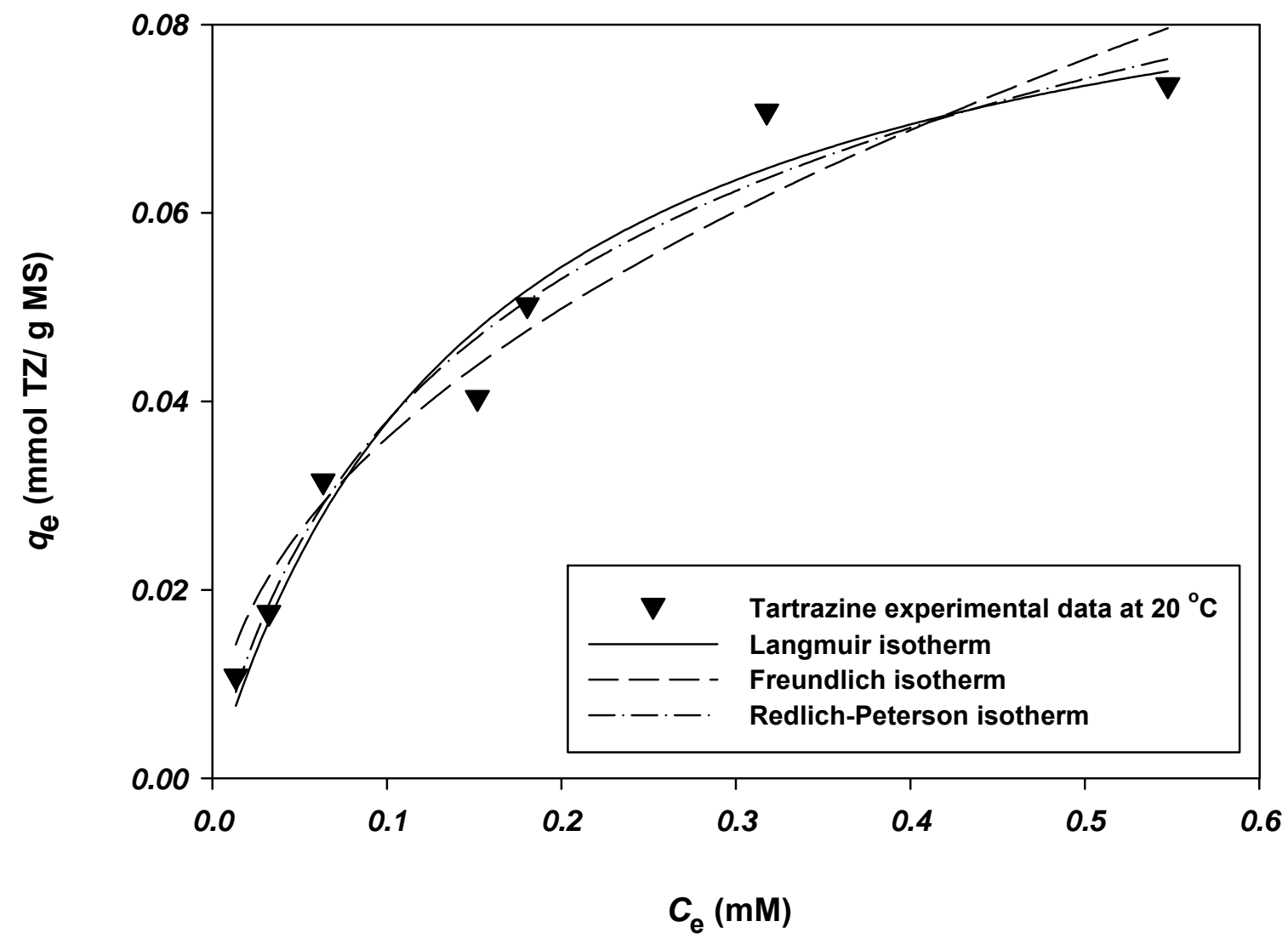

396 Figure 4: Equilibrium isotherm of $\mathrm{TZ}$ experiment data compared to equilibrium isotherm 397 correlations at $20^{\circ} \mathrm{C}$. 


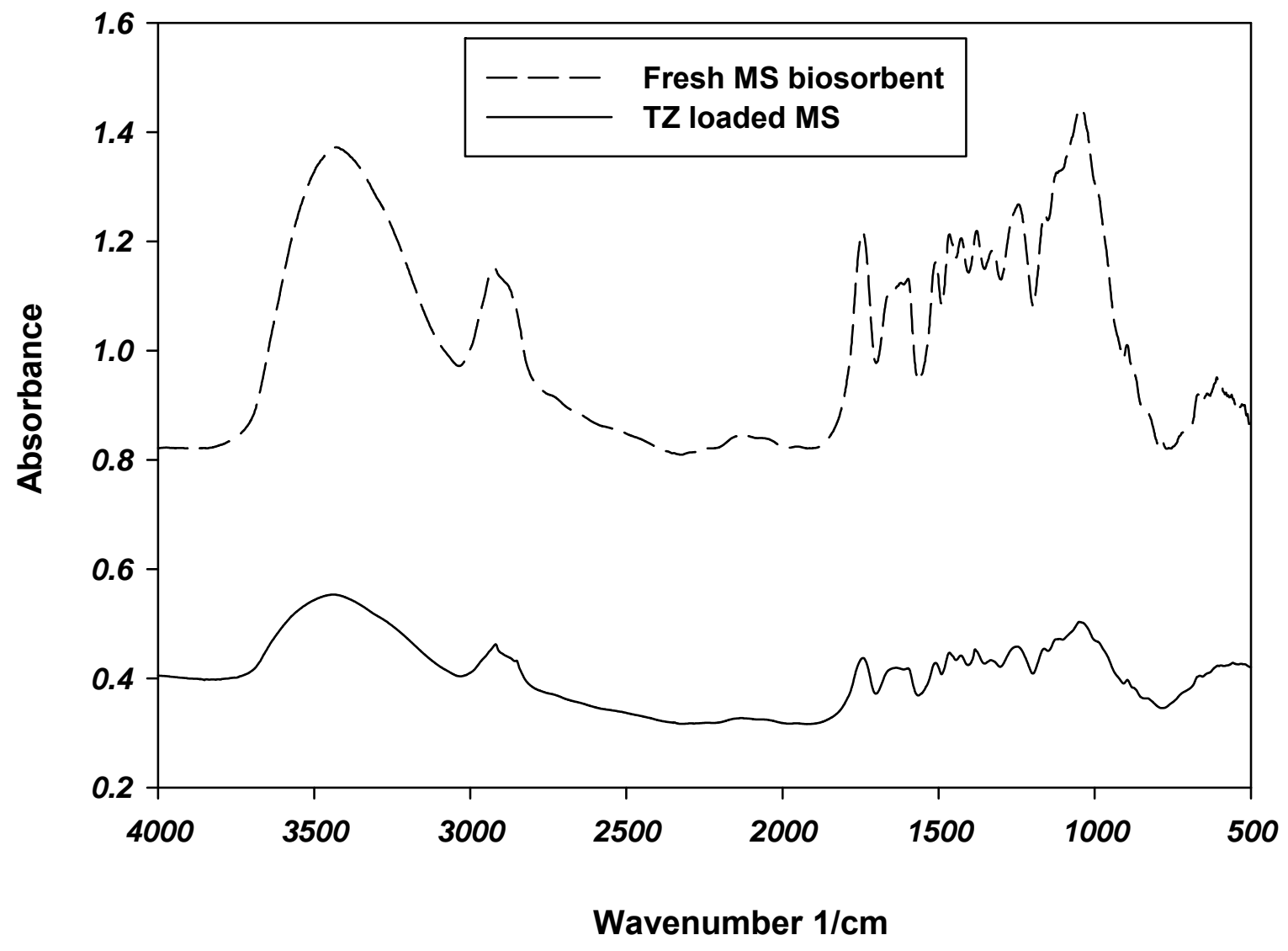

400 Figure 5: FTIR Spectra of fresh and loaded MS.

401 


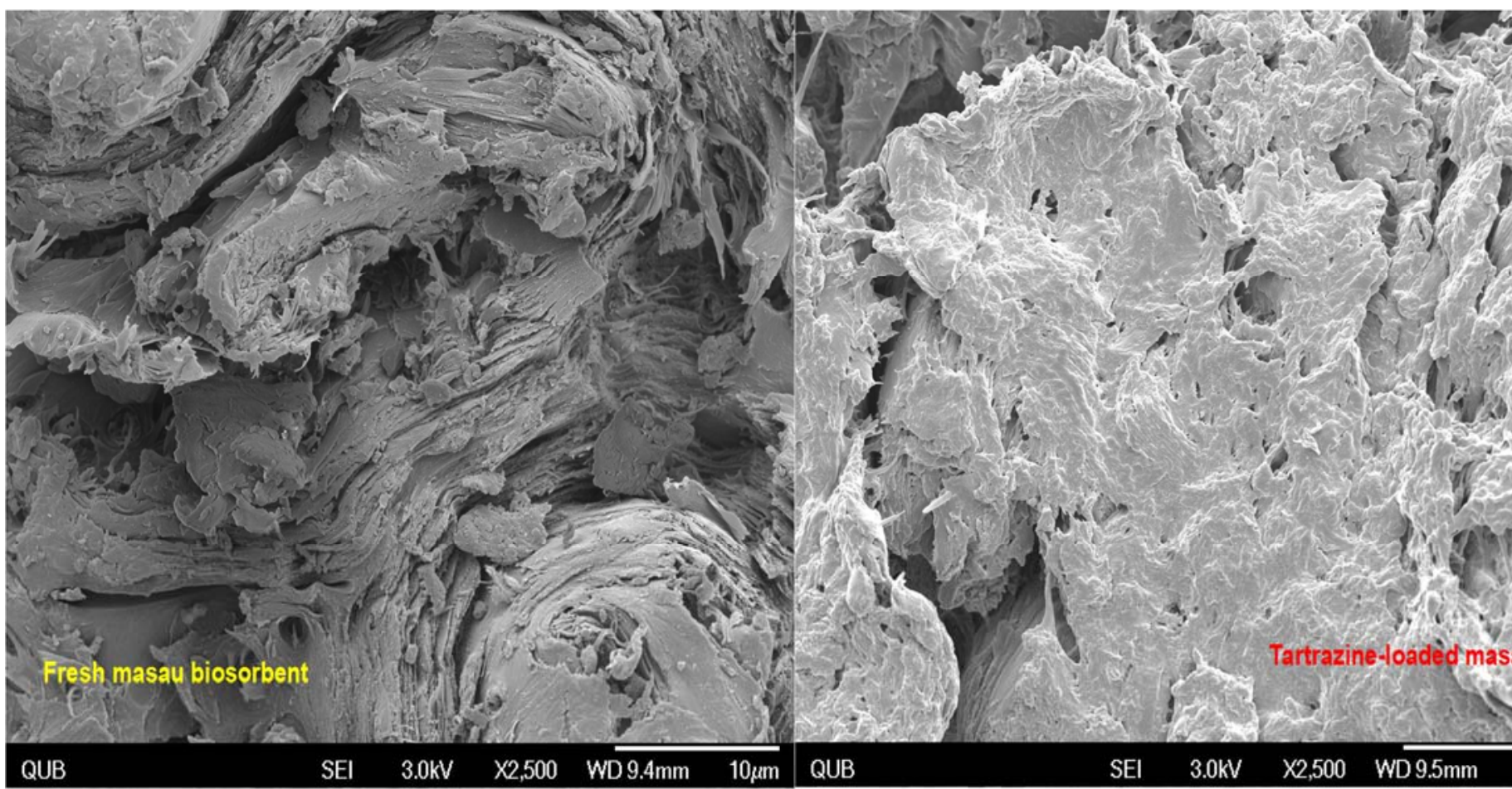

402

403 Figure 6: SEM images for MS before and after TZ biosorption.

404

405

406

407

408

409

410

411

412

413

414

415

416

417

418

419

420

421 
422 Table 1: Pseudo first order and second order kinetic model constants for TZ biosorption onto 423 MS.

\begin{tabular}{|c|c|c|c|c|c|c|c|c|}
\hline & \multirow[t]{2}{*}{$C_{0}(\mathrm{mM})$} & \multicolumn{4}{|c|}{ Pseudo first-order model } & \multicolumn{3}{|c|}{ Pseudo second-order model } \\
\hline & & $\begin{array}{c}q_{\mathrm{e}, \exp } \\
(\mathrm{mmol} / \mathrm{g})\end{array}$ & $\begin{array}{c}q_{\mathrm{e}, \mathrm{cal}} \\
(\mathrm{mmol} / \mathrm{g})\end{array}$ & $\begin{array}{c}k_{1} \\
(1 / \mathrm{min})\end{array}$ & $R^{2}$ & $\begin{array}{c}q_{\mathrm{e}, \mathrm{cal}} \\
(\mathrm{mmol} / \mathrm{g})\end{array}$ & $\begin{array}{c}k_{2} \\
(\mathrm{~g} / \mathrm{mmol} \mathrm{min})\end{array}$ & $R^{2}$ \\
\hline \multirow{7}{*}{$\mathbf{T Z}$} & $0.057(\mathrm{mM})$ & 0.010 & 0.011 & $7.0 \times 10^{-4}$ & 0.988 & 0.014 & 0.048 & 0.988 \\
\hline & $0.102(\mathrm{mM})$ & 0.017 & 0.018 & $7.0 \times 10^{-4}$ & 0.987 & 0.024 & 0.026 & 0.992 \\
\hline & $0.189(\mathrm{mM})$ & 0.031 & 0.031 & $10.0 \times 10^{-3}$ & 0.970 & 0.036 & 0.032 & 0.978 \\
\hline & $0.313(\mathrm{mM})$ & 0.040 & 0.037 & $15.0 \times 10^{-3}$ & 0.976 & 0.040 & 0.041 & 0.987 \\
\hline & $0.381(\mathrm{mM})$ & 0.050 & 0.047 & $12.0 \times 10^{-3}$ & 0.985 & 0.056 & 0.022 & 0.991 \\
\hline & $0.601(\mathrm{mM})$ & 0.071 & 0.056 & $6.7 \times 10^{-3}$ & 0.902 & 0.061 & 0.139 & 0.937 \\
\hline & $0.861(\mathrm{mM})$ & 0.074 & 0.065 & $9.0 \times 10^{-3}$ & 0.804 & 0.067 & 0.248 & 0.887 \\
\hline
\end{tabular}

425

426

427 Table 2: Intra-particle diffusion model parameters for the different diffusion phases.

\begin{tabular}{|c|c|c|c|c|c|c|c|}
\hline & \multirow[t]{2}{*}{$C_{0}(\mathrm{mM})$} & \multicolumn{6}{|c|}{ Intra-particle diffusion coefficients in $\mathrm{mg} / \mathrm{g} . \mathrm{min}^{0.5}$} \\
\hline & & $k_{1 \mathrm{~d}}$ & $R^{2}$ & $k_{2 \mathrm{~d}}$ & $R^{2}$ & $k_{3 \mathrm{~d}}$ & $R^{2}$ \\
\hline \multirow{7}{*}{$\mathbf{T Z}$} & $0.057(\mathrm{mM})$ & $1.0 \times 10^{-4}$ & 0.944 & $3.0 \times 10^{-4}$ & 0.954 & $7.6 \times 10^{-5}$ & 0.979 \\
\hline & $0.102(\mathrm{mM})$ & $2.0 \times 10^{-4}$ & 0.981 & $5.0 \times 10^{-4}$ & 0.934 & $8.0 \times 10^{-5}$ & 0.805 \\
\hline & $0.189(\mathrm{mM})$ & $6.0 \times 10^{-4}$ & 0.898 & $6.0 \times 10^{-4}$ & 0.952 & $4.0 \times 10^{-4}$ & 0.741 \\
\hline & $0.313(\mathrm{mM})$ & $7.0 \times 10^{-4}$ & 0.951 & $6.0 \times 10^{-4}$ & 0.972 & $2.0 \times 10^{-4}$ & 0.790 \\
\hline & $0.381(\mathrm{mM})$ & $1.0 \times 10^{-3}$ & 0.728 & $6.0 \times 10^{-4}$ & 0.981 & $5.0 \times 10^{-4}$ & 0.997 \\
\hline & $0.601(\mathrm{mM})$ & $4.2 \times 10^{-3}$ & 0.910 & $6.0 \times 10^{-4}$ & 0.844 & $6.0 \times 10^{-4}$ & 0.998 \\
\hline & $0.861(\mathrm{mM})$ & $1.1 \times 10^{-3}$ & 0.803 & $5.0 \times 10^{-4}$ & 0.865 & $1.0 \times 10^{-4}$ & 1.000 \\
\hline
\end{tabular}

428 
430 Table 3: The Langmuir, Freundlich and Redlich-Peterson parameters and correlation 431 coefficients for tartrazine (TZ) dye biosorption onto masau stone MS).

\begin{tabular}{llcccc}
\hline Model & Parameters & $\mathbf{2 0}^{\circ} \mathbf{C}$ & $\mathbf{3 0}^{\circ} \mathbf{C}$ & $\mathbf{4 5}^{\circ} \mathbf{C}$ & $\mathbf{6 0}^{\circ} \mathbf{C}$ \\
\hline Langmuir isotherm & $q_{\max }$ & 0.096 & 0.115 & 0.122 & 0.126 \\
$q_{e}=\frac{q_{\max } b C_{e}}{1+b C_{e}}$ & & $(51.3 \mathrm{mg} / \mathrm{g})$ & $(61.4 \mathrm{mg} / \mathrm{g})$ & $(65.1 \mathrm{mg} / \mathrm{g})$ & $(67.4 \mathrm{mg} / \mathrm{g})$ \\
& $b$ & 6.460 & 6.609 & 8.237 & 12.70 \\
& $R^{2}$ & 0.986 & 0.992 & 0.981 & 0.978 \\
\hline Freundlich isotherm & $K_{\mathrm{F}}$ & 0.105 & 0.138 & 0.151 & 0.159 \\
$q_{e}=K_{F} C_{e}^{1 / n}$ & $1 / n$ & 0.556 & 0.505 & 0.454 & 0.401 \\
\hline Redlich-Peterson isotherm & $R^{2}$ & 0.974 & 0.986 & 0.995 & 0.996 \\
$q_{e}=\frac{K_{R}}{1+a_{R} C_{e}^{\beta}}$ & $a_{\mathrm{R}}$ & 0.834 & 0.919 & 5.990 & 29.89 \\
& $\beta$ & 8.246 & 6.917 & 40.30 & 189.2 \\
& $R^{2}$ & 0.835 & 0.823 & 0.616 & 0.602 \\
\hline
\end{tabular}

432 Where: $q_{\max }(\mathrm{mmol} / \mathrm{g}) ; b\left(\mathrm{dm}^{3} / \mathrm{mmol}\right) ; K_{\mathrm{F}}\left((\mathrm{mg} / \mathrm{g}) \cdot\left(\mathrm{mg} / \mathrm{dm}^{3}\right)^{\mathrm{n}}\right) ; n($ dimensionless $) ; K_{\mathrm{R}}\left(\mathrm{dm}^{3} / \mathrm{g}\right)$;

$433 \quad a_{\mathrm{R}}\left(\mathrm{dm}^{3} / \mathrm{mg}\right)$; and $\beta$ (dimensionless).

434

435 Table 4: Comparison between various adsorbents for the removal of TZ.

\begin{tabular}{lll}
\hline Adsorbent & $\boldsymbol{q}_{\mathbf{m a x}}(\mathbf{m g} / \mathbf{g})$ & Reference \\
\hline Hen feathers & 64.1 & {$[17]$} \\
Spirulina platensis & 363.2 & {$[20]$} \\
De-oiled soya & 24.6 & {$[33]$} \\
Bottom ash & 12.6 & {$[33]$} \\
Activated carbon & 121.3 & {$[34]$} \\
Crosslinked Chitosan-Coated Bentonite & 294.1 & {$[35]$} \\
Masau stone & $51.3(0.096 \mathrm{mmol} / \mathrm{g})$ & This study \\
\hline
\end{tabular}

436

437 Table 5: Thermodynamic parameters

\begin{tabular}{llllll}
\hline$\Delta \mathrm{H}(\mathrm{kJ} / \mathrm{mol})$ & $\Delta \mathrm{S}(\mathrm{J} / \mathrm{mol} \mathrm{K})$ & \multicolumn{4}{l}{$\Delta \mathrm{G}(\mathrm{kJ} / \mathrm{mol})$} \\
& & $293 \mathrm{~K}$ & $303 \mathrm{~K}$ & $318 \mathrm{~K}$ & $333 \mathrm{~K}$ \\
\cline { 2 - 5 } 13.69 & 152.3 & -31.15 & -32.27 & -34.46 & -37.28 \\
\hline
\end{tabular}


439

440

441

442 